\title{
ECOTONE VEGETATION AND WATER QUALITY OF RARA AND BEGNAS LAKES, NEPAL
}

\author{
Furbe Lama ${ }^{1 *}$, Sudeep Thakuri ${ }^{1}$, Narayan Prasad Ghimire ${ }^{2}$, Rabin Malla ${ }^{3}$ \\ ${ }^{1}$ Central Department of Environmental Science, Tribhuvan University, Kathmandu \\ ${ }^{2}$ Central Department of Botany, Tribhuvan University, Kathmandu \\ ${ }^{3}$ Center of Research for Environment, Energy and Water, Baluwatar, Kathmandu \\ Corresponding Author: lamafurbu7@gmail.com
}

\begin{abstract}
Land-water interfaces of lakes are highly dynamic and are responsible for the stability and maintenance of ecosystems. This study was carried out to understand the ecotone vegetation and the physico-chemical characteristics of waters of Begnas and Rara lakes of Nepal. For vegetation survey, line transects (perpendicular bi-sector to lake boundary), were used along the lake boundaries at an interval of $500 \mathrm{~m}$; three quadrats of $1 \mathrm{~m} \mathrm{x} 1 \mathrm{~m}$ size were laid on each line transect (off shore, boundary line, and on shore). All vegetation species in the sample quadrates were recorded. For probing water quality, lakes were divided into three blocks, then sampling was conducted on a consecutive day. Physico-chemical parameters - temperature, $\mathrm{pH}$, electric conductivity (EC), dissolved oxygen (DO), total dissolved solid (TDS), ammonia, and nitrate-were measured. A total of 55 species under 38 families and 28 orders were recorded from ecotone of Begnas lake. In Rara lake, 56 species of 41 families and 22 orders were recorded. Poaceae was the dominant largest family in Begnas which was followed by Asteraceae. In Rara lake, Rosaceae was the dominant family which was followed by Pinaceae. Temperature, $\mathrm{pH}$, and DO values decreased with depth, but EC and TDS e increased with depth, in both Begnas and Rara lakes. Ammonia and Nitrate were below the detectable limit of the instrument, indicating low nutrient contents of both lakes. The study established the baseline information about the diversity of ecotone vegetation; both the lakes show clear changes in physiochemical parameters with lake depths.
\end{abstract}

Key words: Begnas, ecotone, floral diversity, physico-chemical, Rara.

\section{INTRODUCTION}

Water body could be defined as lakes according to their depth, temporality or in terms of their underwater topography (Onorato et al., 2017). Lake ecology is intended to provide a general background to lake access by introducing basic concepts necessary to understand how the lake ecosystem functions. The lake ecology is described by fundamental physical, chemical and biological characteristics of lakes (Teneva et al., 2014). The ecological function and services of wetlands are essential for the sustainable development of lives (Gurung et al., 2009).
Ecotones are transition areas between different natural systems (ecosystems, landscapes), between natural and anthropogenic systems, between different media (water-land), and between biomes (Ivanova and Soukhovolsky, 2016). The ecological environment of land-lake ecotone is complex and changeable. It is an important water purification area and pollution buffer zone, where the microorganisms play an important role in the mediation of material cycle, nutrition transfer, and element transformation (Huang et al., 2016). Wetland's ecotones are amongst the richest life supporting ecosystem 
and they are most threatened due to various biotic stresses (Singh, 2013). Vegetation refers to the great diversity of plant species which occur in assemblages over the face of the earth (Johnston et al., 2007). Floral assessment is an important criterion for the assessment of life forms and habitat for an area (Klosowski, 1993). Riparian vegetation is a typical element of the lake district landscapes (Ivanova and Soukhovolsky, 2016). In the world, wetlands and their associated species are under pressure of decline and system degradation. Change in land and water use, water discharge, environmental condition and structure can all have profound effects on the functioning of a lake (Olubode $e t$ al., 2011). An understanding of individual plant species is the first step in developing indicators of the ecological condition of a lake (Johnston et al., 2007) because the indices based on plant assemblages rely on the cumulative behavior of individual species (Klosowski, 1993). The lakeshore affects in the littoral zone and lake ecosystems ( $\mathrm{Lu}$ et al., 2016) which provides physical structure, alters water movements and hydrological processes and affects the transport of organic materials within the aquatic environment (Teneva et al., 2014). Presence of exotic species threatened the native species and effects on the status of a lake (Palmik et al., 2013).

Water quality generally means the component of water which must be present for optimum growth of aquatic organisms (Verma and Khan, 2015). It is very essential and important to test the water before it is used for drinking, domestic, agricultural or industrial purpose. Selection of parameters for testing of water solely depends upon for what purpose we are going to use that water and what extent we need its quality and purity (Patil et al., 2012). Water quality assessment defines the status and trend in water quality, identify the specific problems of water quality and provide the strategy of management. Monitoring water quality is an essential activity that makes use of water sources (Udhayakumar et al., 2016). The determinant of good growth in water body includes dissolved oxygen, hardness, turbidity, alkalinity, nutrients, and temperature. Conversely, other parameters like biological oxygen demand and chemical oxygen demand indicate pollution level of a given water body (Verma and Khan, 2015). All the aquatic life depends on the stability of water chemistry; thus, any significant changes in the lentic systems can lead to imbalance and adverse impacts on the organisms dwelling therein. Due to the increased human population, industrialization, use of fertilizers and manmade activity, water is highly polluted with different harmful contaminants (Patil et al., 2012). Deterioration of the water quality is now a very big problem. Increasing water pollution causes not only the change of water quality but also threatens human health and the balance of aquatic ecosystems, economic development, and social prosperity (Verma and Khan, 2015). The present study attempts to determine the ecotone vegetation status and water quality of Rara and Begnas lakes. The study focused on the documentation of ecotone floral diversity and depth wise variation of physico-chemical parameters of water of the lakes.

\section{MATERIALS AND METHODS}

\section{Study area}

This study was conducted in two freshwater lakes of Nepal, Rara and Begnas lakes. These lakes were selected due to their locations in two different geographic settings with distinct climatic characteristics.

Begnas lake is the second largest lake of the Pokhara valley which is situated in 
the subtropical region of central Nepal at an elevation of $650 \mathrm{~m}$ above the sea level. It lies in 28 $10^{\prime} 26^{\prime \prime}$ North latitude and $84^{\circ} 05^{\prime} 50^{\prime \prime}$ East longitude, at Kaski district of Nepal. Begnas lake along with other eight lakes around its periphery (in Pokhara and Lekhnath) has been designed as the $10^{\text {th }}$ Ramsar site of Nepal (Rai et al., 2000).
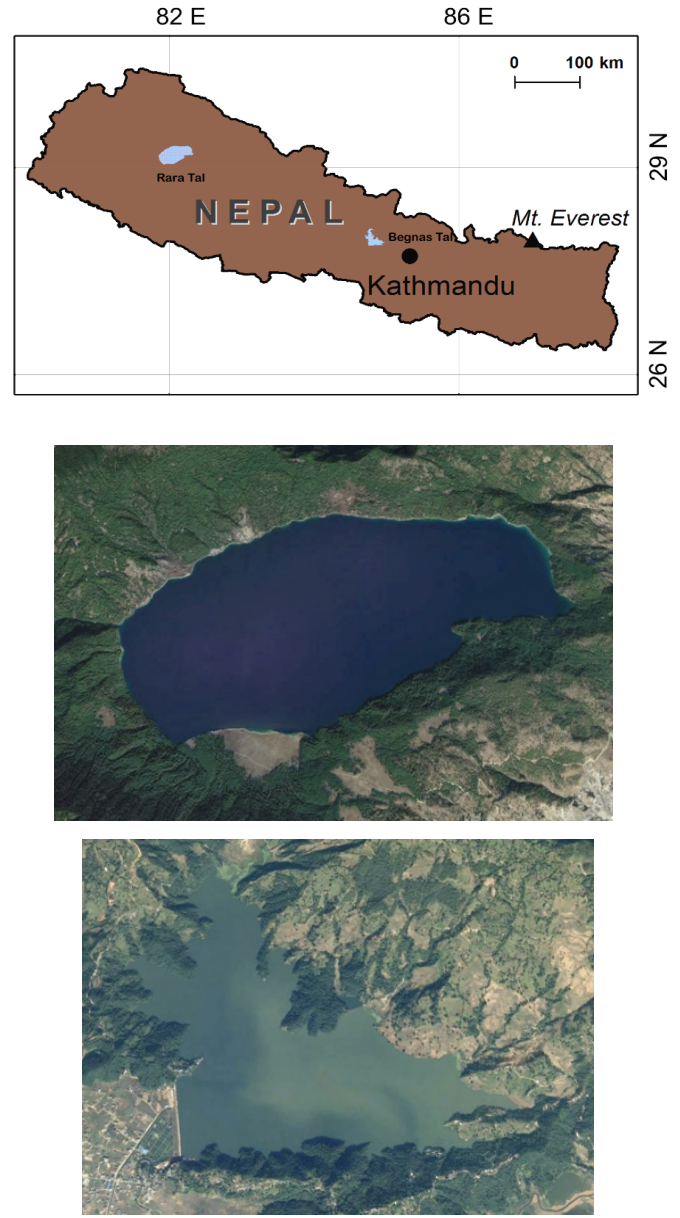

Fig. 1 Study sites: Begnas and Rara lake

Rara lake is the biggest and the deepest lake of Nepal. It is a high-altitude alpine lake, situated in Rara National Park, mid-western Nepal. It lies in $29^{\circ} 31^{\prime} 45^{\prime \prime}$ North latitude and $82^{\circ} 05^{\prime} 35^{\prime \prime}$ East longitude, at Mugu district of Nepal. The lake was declared as a Ramsar site in 2007. The lake has been a popular destination with a very rough route in western Nepal for trekkers. The lake is surrounded by Rara National Park (RNP) with pine, spruce, and juniper forest.

\section{Sampling design}

The study was conducted by systematic sampling (USGS/NPS, 1994). Three lines transect at the ecotone of lakes i.e. onshore, boundary and offshore was established (Buckland et al., 2007). Location, slope, altitude and aspect of sampling point were noted by using a compass and a global positioning system (GPS). At the interval of every $500 \mathrm{~m}$, three quadrats of $1 \mathrm{~m}$ X $1 \mathrm{~m}$ were laid (USGS/NPS, 1994) on each line transect (one onshore-Q1, one on the landwater border line-Q2, one off shore-Q3) and all plant species recorded in the quadrates were noted. All the strata were noted i.e., trees, shrubs and herbs. The different plant species from the quadrate was also noted. The plant specimens under different families were collected as the herbarium specimens. The herbarium specimens were made only from Begnas lake, while we were unable to collect the herbarium from Rara lake due to ethical issues associated with the collection from the conservation area (Rara national park) lake. The data were further analyzed in accordance with family, order, generic and specific names. The collected specimens were thoroughly examined and identified (Shrestha, 1998); www.IPNI.org and http://www.efloras.org/flora_page.aspx?flora $\mathrm{id}=110$ ). The plant specimens were crosschecked with the photographs and herbarium specimens at National Herbarium and Plant Laboratory (NHPL).

Consecutive day sampling during the study period was used. The physico-chemical parameters, such as temperature, $\mathrm{pH}$, conductivity, dissolved oxygen (DO), total dissolved solids (TDS), nitrate and ammonia were measured on the spot in different depths of 
the water column. Grab sampling was adopted for physico-chemical parameter analysis of water by collecting water sample at a particular time and place that represents the composition of the source at that particular point and time. In both Begnas and Rara lakes, three blocks of the lake were established to measure the physico-chemical parameters of water columns. Blocks are named as block "A", block "B" and block "C". In Begnas lake, block "A" was not connected to either inlet or outlet, block "B" was connected to an outlet of the lake and block "C" was connected to inlet of the lake. Grab sampling was done at the inlet, center and outlet in the lake. In Rara lake, block "A" was connected with an outlet, block "B" was connected with grazing field, and block " $\mathrm{C}$ " was connected mostly forest touching line. In each block, we marked the five sampling points. The GPS coordinates of each point were recorded. From each sampling point, the depth wise result of physico-chemical parameters was measured. All the sample collection techniques, quality control technique and analytical methods were followed by using the standard methods for the examination of water and wastewater (APHA, AWWA, and WEF, 1998).

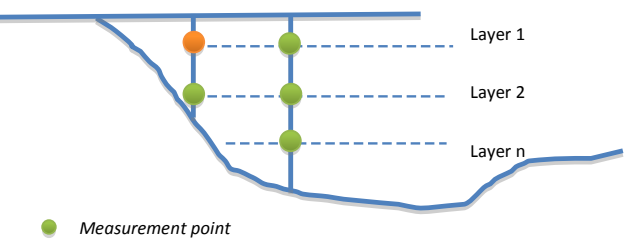

Fig. 2 Sampling design for the depth-wise physicochemical data

\section{Data analysis and interpretation}

The collected data were subjected to further analysis. Ecotone vegetation and physicochemical characteristics data of water were analyzed by using MS Excel. The data were analyzed by both quantitative (by using statistics) and qualitative (simply by narration) statistical tools, as applicable and presented in the figures and tables. A floristic similarity among the ecotone of Begnas and Rara lake was carried out using the Jaccard's similarity coefficients (JSC). For this purpose, plant species were compared by their pair and then, clustered on the basis of $\mathrm{JSC}=\mathrm{C} /(\mathrm{A}+\mathrm{B}-\mathrm{C})$, where $\mathrm{A}$ and $B$ are species number in samples and $C$ is the number of species shared by the two samples. The mathematical work was done with a simple calculation. The descriptive language and tables were also used to analyze and were interpreted.

\section{RESULTS AND DISCUSSION}

\section{State of ecotone vegetation}

In ecotone of Begnas lake, a total of 59 plant species were recorded. Among the 59 species, four species were unidentified and the rests 55 species were of 38 families and 28 orders. The study found Poaceae and Asteraceae to be the largest family having 5 species in the ecotone of Begnas lake followed by Fabaceae with 4 species, Lamiaceae with 3 species and Poaceae, Drypteraceae, Malvaceae, Polygonaceae, and Myrtaceae with 2 species. Single species was found in other families. Similarly, Asterales and Poales were teh largest order having 6 species followed by Fabales, Polygonales, and Lamiales with 4 species, Malvales, Caryophyllales and Fagales with 3 species, Ranuculales and Myrtales with 2 species, and remaining orders had single species of flora.

Inside the Begnas lake, only 3 species were recorded. The 3 species recorded are Eichhornia crassipes, Nymphoides hydrophyllum, and Paani Jhar (in Nepalese language). At the inlet, there was a higher number of aquatic plants. There was a higher number of E. crassipes, N. hydrophyllum, and Paani Jhar. At the dam, mostly herb species and one tree of Sapium 
insigne were recorded. At the forest side of all sampling plot, many individuals of Pteridium revolutum and tree species were recorded. Most of the trees were Shorea robusta, Schima wallichi, and Castonopsis indica. Over all forest near to Begnas lake was dominated by these three species of tree. At human disturbed area, there was higher number of herb species. Most of the species of Paspalum distichum, Trifolium ripens, Cyperus rotondus, and Cynodon dactylon were recorded in human disturbed, barren and agricultural disturbed area.

A total of 61 flora species were recorded from the ecotone of Rara lake. Among them, five species remained unidentified and rests of the 56 species belong to 41 families and 22 orders. The study found that Rosaceae was the largest family having 8 species followed by Pinaceae with 5 species, Asteraceae with 3 species and Poaceae, Cyperaceae, Polygonaceae, Papaveraceae, Primulaceae, Fabaceae and Berberidaceae with 2 species. Other families were found with single species. Similarly, the Rosales was the largest order having 8 species followed by Pinales with 7 species, Poales with 5 species, Caryophyllales and Ranuculales with 4 species, Ericales, Asterales, Lamiales and Gentianales with 3 species and Saxifragales and Fagales with 2 species. And remaining order of single species was recorded.

Regarding the diversity of the species in the ecotone of Rara lake, the least number of species was observed under the pine forest. The high number of herbaceous plant were recorded near to Millichaur along the side of pasture land. Only few numbers of aquatic species (macrophytes) were recorded in the lake. Only two aquatic species of Phragmites karka and Sebaro (local name) was observed in lake water. And species of family Cyperaeae and Polygonaceae were found in semi-aquatic habitats. Some ecotone species was unidentified in both Begnas and Rara lakes and in some cases of species they were classified only at family level and some were unable to classify in family and order. Only four common species were recorded in ecotone of both lakes. The species common to both are Centella asiatica (L.) Urb., Cynodon dactylon (L.) Pers., Dryopteris flix-mas (L.) Schott, Trifolium repens $\mathrm{L}$.

The species encountered in both the lakes represent three ecological groups: trees, shrubs and steppe vegetation. Herb species were mostly recorded. A higher number of species were recorded at the line transect of the boundary of the lake ecotone and a nearly equal number of species were recorded at the line transect of offshore. A small number of species was recorded at the line transects of onshore.

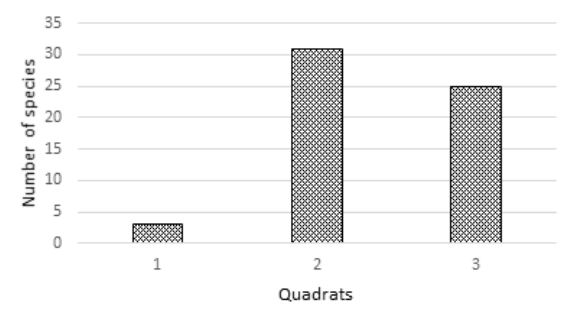

Fig. 3 Species number recorded at onshore, boundary and

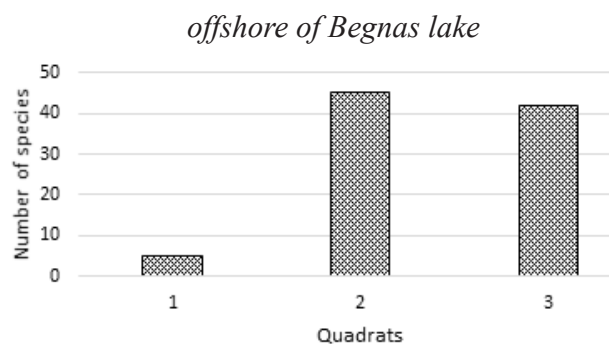

Fig. 4 Species number recorded at onshore, boundary and offshore of Rara lake

The present investigation revealed baseline information about floras status, invasiveness and endemism of plants around the ecotone of Begnas and Rara lake. The ecotone vegetation status was also manifested in plant habits which included herbs, shrubs, trees, climbers and 
epiphytes with a clear dominance of herbaceous species (Talukdar, 2013). The result indicates that the ecotone vegetation is composed of various types of phytocoenoses, which are connected with the land-lake systems but most of the vegetation were of terrestrial habitat. The vegetation types found in Begnas and Rara lakes, often form characteristics zonation's, which distinguish themselves with respect to lake valley landscape. The spatial distinction of communities demonstrated that the riparian vegetation zone constituted an internally differentiated ecotone (Klosowski, 1993).

Both the lakes were found dominated by native plants (Lemein et al., 2017) but at Begnas lake an invasive species of Eichhornia crassipes is also present. As E. crassipes stands the worst aquatic weed throughout the tropics and subtropics, increasing of E. crassipes is a sign of the increase in cultural eutrophication and siltation. But the low occurrence of E. crassipes in the lake can be attributed to the low impact of eutrophication in lake (Basnet, 2010). The distribution of invasive species characterizing stress including high runoff from intense agriculture, hydrologic and physical alteration and chemical pollution in Begnas lake. The spread of these alien and invasive weeds in the present study area is quite alarming to the conservation of native biodiversity. The presence of forest of Shorea rubusta, Castonopsis indica and Schima wallichi revealed that plant diversity in moist forest at the ecotone. Although medicinal importance and resource utilization of plant species is integral part of the livelihood, the study could not invent the medicinal value due to limit time. The species $C$. dactylon was the most efficient riparian species in conservation of soil, water and nutrients in surface runoff (Talukdar, 2013). In Rara three endemic species of Nepal, Meconopsis regia G. Taylor, Primula poluminni
Fletcher and Cirsium flavisquamatum Kitam were recorded 1 (Basnet, 2010).

Only the four species in the ecotone of both lakes were recorded as the common species. Less number of common species might be due to two lakes situated in the different geographic and climatic region (Lemein et al., 2017). Jaccard's similarity index was found to be $3.44 \%$ which clearly showed that the communities under studies i.e. ecotone vegetation of Begnas and Rara was different from each other. The communities were dissimilar. So the communities were heterogeneous in nature (Palmik et al., 2013). The dissimilarity of the communities was due to different climatic condition, temperature, nutrient content, human approaches and etc (Lemein et al., 2017). The chemical and physical gradients influence the biota in many ways so species of ecotone of the lake does not depend on salinity alone but is the result of complex of factors (Reizopoulou et al., 2013). Soil clay content and consequently, water retention capacity of the soil could have contributed to the occurrence of species (Olubode et al., 2011). The variety of communities are obviously related to differences between the typical habitats around both lakes and the environmental conditions provided by the palaeshoreline (Nowak et al., 2017). The differences in species composition could have been due to differences in edaphic factors. Farming and fishing activities which were actively carried out around the Begnas lake that is indicative of the influence of man related disturbances on the flora of the study sites. Variation in species composition of each lake suggests that the flora of different lakes was brought about by edaphic and anthropogenic factors in the areas (Olubode et al., 2011).

The ecotone of the lake is characterized by extremely high concentrations of dissolved substances and spatially variation in chemical 
composition with the seasonal fluctuation of water levels, the accumulation can be disadvantageous phenomenon since the waters of lakes become enriched with nutrients after the mineralization of the shore (Klosowski, 1993). Increase in nutrient content does not result in their immediate release into the river water, however, the processes of nutrient release are often initiated by the impact on riparian vegetation (Talukdar, 2013). The human and agricultural disturbances in Begnas lake, leading to changes in the water regime and initiation of erosive processes which have the strongest negative impact on riparian vegetation (Klosowski, 1993) and also it will be in Rara if any step not taken against the disturbances.

\section{Physio-chemical parameters of water}

The present study involved in the analysis of water quality in terms of physio-chemical parameters of Begnas and Rara lakes of Nepal. The information was collected up to $5 \mathrm{~m}$ depth and $10 \mathrm{~m}$ depth for Begnas lake and Rara lake respectively. Even in few meters' depth variations in all the parameters were clearly observed in Begnas lake. In the case of Rara lake, a low variation of the parameters within the depth of 10 meters was observed. The results of both lakes were obtained as follows.

Water temperature: Rara lake being the lake in the higher altitude itself has a low temperature in comparison with the temperature of Begnas lake. The study showed that the temperature of Rara lake decreased slightly from $17.7{ }^{\circ} \mathrm{C}$ to $16.7^{\circ} \mathrm{C}$ going $10 \mathrm{~m}$ depth in the temperature in comparison to the temperature of Begnas lake from $29.5^{\circ} \mathrm{C}$ to $27.1{ }^{\circ} \mathrm{C}$ going $5 \mathrm{~m}$ depth. The average temperature of Begnas was found at 28.3 ${ }^{\circ} \mathrm{C}$ and Rara 17.1 C. The temperature decreased with the increase of depths. The temperatures of both lakes are as shown in figure 5 .

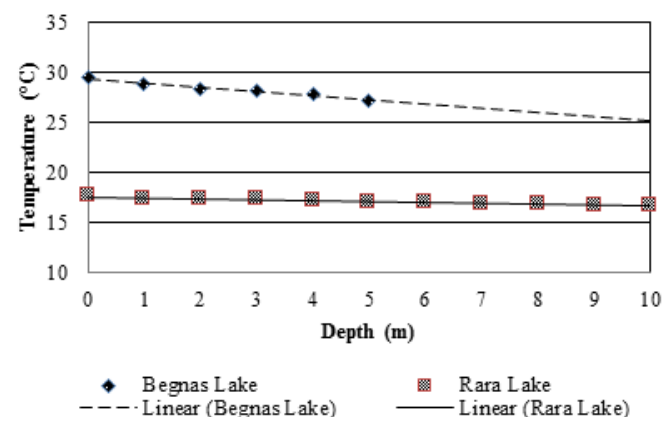

Fig. 5 Temperature variation in Begnas and Rara lakes

pH: In Begnas lake, the $\mathrm{pH}$ was recorded between 6.2 and 5.2 and in Rara lake, between 6.6 and 6.3. There was not much of change in the $\mathrm{pH}$ with a depth of Rara lake. The high $\mathrm{pH}$ was recorded at the surface of the lake and found decreasing with increasing of depth. The mean $\mathrm{pH}$ was found 5.9 in Begnas lake and 6.3 in Rara lake. The $\mathrm{pH}$ of both lakes is as shown in figure 6.

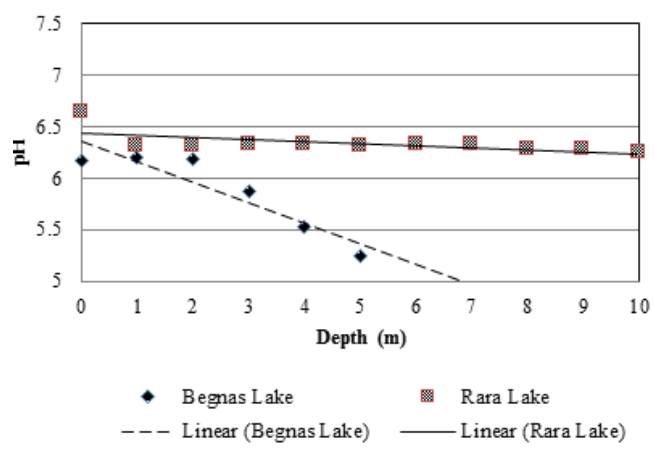

Fig. 6 pH variation in Begnas and Rara lakes

Dissolved oxygen: The dissolved oxygen in Begnas lake was 7.3 to $6.5 \%$ and that of Rara lake was found to be 6.4 to $5.8 \%$. The mean DO in Begnas was found 7.1 and $6.2 \%$ in Rara lake. The DO was found decreasing with the increase of depths in both lakes. The DO of both lakes is as shown in figure 7 . 


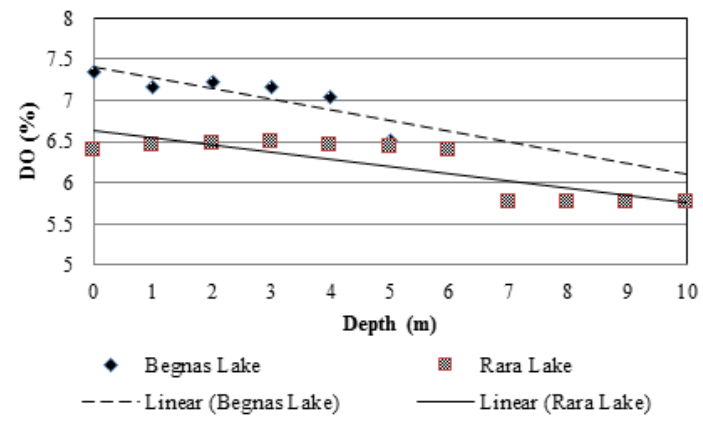

Fig. 7 DO variation in Begnas and Rara lakes

Electrical conductivity: The electrical conductivity in Rara lake was found to be from 19.50 to $25.37 \mu \mathrm{S} / \mathrm{cm}$ and that of Begnas lake was 30.33 to $38.78 \mu \mathrm{S} / \mathrm{cm}$. It was seen in both the lakes that the electrical conductivity was increasing with the increase in depth. This result showed that Begnas lake had higher EC value than the permissible limit and Rara lake had within the limit. The mean EC was found 35.05 $\mu \mathrm{S} / \mathrm{cm}$ in Begnas lake and $23.24 \mu \mathrm{S} / \mathrm{cm}$ in Rara lake. The EC of both lakes is as shown in figure 8 .

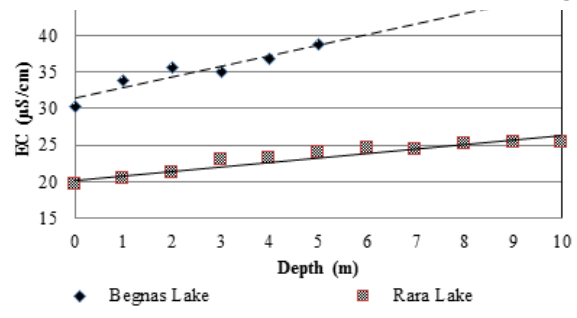

Fig. 8 EC variation in Begnas and Rara lakes

Total dissolved solid: The total dissolved solid of Rara lake was 9.44 to $13.93 \mathrm{mg} / \mathrm{l}$ and Begnas lake 14.11 to $17.89 \mathrm{mg} / \mathrm{l}$. The mean TDS was found $16.12 \mathrm{mg} / \mathrm{l}$ in Begnas and $11.81 \mathrm{mg} / \mathrm{l}$ in Rara. Since there were few aquatic- lives and few external influences in the Rara lake, this lake had less total dissolved solid. On the other hand, Begnas lake had high total dissolved solid in comparison to Rara lake because of the presence of high aquatic life due to optimum temperature and because of external influences. The TDS of both lakes are as shown in figure 9 .

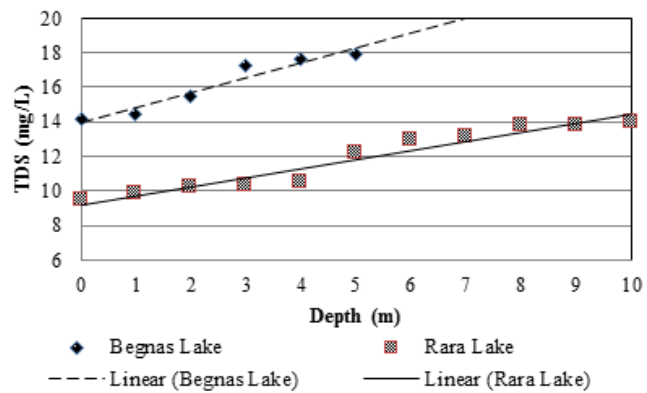

Fig. 9 TDS variation in Begnas and Rara lakes

In both lakes, the trace amount of ammonia and nitrate was found. So, the nutrient content in both lakes was less amount. The result in both the lakes showed that the temperature of the plots decreases with an increase in the depth. Temperature effects on the chemical and biological reaction in water (Patil et al., 2012). The sunlight couldn't penetrate to the bottom of the lake if the lake is too deep. With increasing of the depth, the light intensity decreased. This caused the decrease in the temperature with increase in depth. Temperature, directly and indirectly, influenced to abiotic and biotic components of the aquatic ecosystem (Verma and Khan, 2015).

Change in $\mathrm{pH}$ showed that there were a few chemical and biological reactions in water (Rai, 2000). The water of Begnas lake has become highly acidic in comparison with the result of the study of Rai (2000). The result showed that the nature of water of both the lake had completely changed. In the case of Begnas lake, there was more chemical and biological reaction in water than that of Rara lake. The altitude difference might be one of the reasons for this result (Raut et al., 2012). Because of the altitude difference, there was a difference in temperature between these two lakes, and the temperature is responsible for the chemical and biological reactions (Alam et al., 2017). The decrease in $\mathrm{pH}$ i.e. increase in acidity might be because of the surface flow of different types of chemical 
fertilizers, pesticides etc. from the surrounding agricultural lands. The human influences also had been increased; this might also be a cause for the increase in the acidic nature of both the lakes (Patil et al., 2012). The study also showed that the acidic nature of the lakes increases with the increase in depth, one of the causes might be due to high TDS content in the depth than in the surface (Udhayakumar et al., 2016). The $\mathrm{pH}$ of Begnas lake was highly acidic with increase in depth as compared with the $\mathrm{pH}$ of Rara lake. The dissolved oxygen is less in Begnas lake in comparison with the result obtained by Rai (2000). The dissolved oxygen was higher in Begnas lake than in Rara lake. This showed that the aquatic life was less in Rara lake than in Begnas lake (Rai, 2000). The high DO was seen in high temperature, it might be due to bright sunlight influence on the percentage of soluble photosynthesis by phytoplankton, utilizing carbondioxide and giving off oxygen (Patil et al., 2012). The survival rate of aquatic life was found high in Begnas lake (Raut et al., 2012). Dissolved oxygen levels are considered as the most important and commonly employed measurement of water quality and indicator of a water body's ability to support desirable aquatic life. Like terrestrial animals, fish and other aquatic organisms need oxygen to live (Patil et al., 2012). Rara lake was oligotrophic based on DO estimation but Begnas lake was slightly polluted. Due to less dissolved oxygen in Rara lake, the aquatic life is less and the activity under water is also low. In the case of Begnas lake, the aquatic life is remarkably high and the underwater activity is also in comparison with that of Rara lake. It is correlated with water body directly and indirectly for the information of bacterial activity, photosynthesis, availability of nutrients and stratification (Kora et al., 2017). As per WHO standard DO value of $5 \mathrm{mg} / \mathrm{l}$ is ideal. The dissolved oxygen is responsible for the presence of aquatic life and all biological reactions in water. The higher value of dissolved oxygen could impart good aesthetic taste to drinking water (Raut et al., 2012). The dissolved oxygen also decreases with the increase in rate of oxidation of organic matter and metabolic rate of organisms (Kora et al., 2017).

The electric conductivity seemed to be higher as deeper the lake becomes. This might be because of TDS settling down at the bottom (Verma and Khan, 2015). The cations and anions might be in a higher amount in the TDS. In both the lakes, the electric conductivity was increasing with depth but Begnas lake showed higher conductivity than Rara lake. The cause behind this result might be because of the human influences at Begnas lake (Raut et al., 2012). This also might suggest Rara lake being slightly acidic than Begnas lake. It could be concluded from the result that near the bottom of the lake there was a higher concentration of the ionized salts (Verma and Khan, 2015).

The increase in the total dissolved solid with depth because these were standing water bodies and the dissolved solid tends to settle at the bottom of the lake. The total dissolved solids in Begnas lake was higher than that of Rara lake. TDS indicates the salinity behavior of water. The total dissolved solids in water were due to the presence of all inorganic and organic substances (Patil et al., 2012). Begnas lake seems to have the presence of more inorganic and organic substances. Higher values of TDS might be because of human interference and the runnoff from the agricultural lands (Raut et al., 2012). The high percentage of TDS also imparts alkalinity nature to water (Patil et al., 2012).

The domestic sewage was received slightly high in Begnas lake due to surface runoff from the agricultural land and human disturbances. The 
agriculture effluents were not presented in Rara lake but there is a presence of animal excreta due to grazing nearby the lake. These clearly indicate that there is less presence of nutrient i.e. nitrate and ammonia in both the lakes. This study shows that both the lakes are slightly influenced by anthropogenic activities.

\section{CONCLUSIONS}

This study established baseline information about the diversity of ecotone vegetation in Begnas and Rara lakes of Nepal. Most of the species were of terrestrial habitat. Both Begnas and Rara, lakes showed clear changes in physico-chemical parameters with lake depths and study showed both the lakes are influenced by anthropogenic activities. This study may give vital clues in the conservation of floral diversity and natural ecosystem of the two lakes and their surroundings.

\section{ACKNOWLEDGEMENTS}

This study was supported by the CREEW-Young Researcher Fellowship. Our special thank goes to Mr. Lokendra Subba and Mr. Sabin Shakya, who contributed during the fieldwork. Further, we express our sincere thanks to the Head of Department and all teaching faculties in the TU-CDES, the Begnas lake Management Committee, and the Rara National Park Office for their kind cooperation during the study.

\section{REFERENCES}

Alam, M.Z., L. Carpenter-Boggs, A. Rahman, M. Haque, R.U. Miah, M. Moniruzzaman, A. Qayum, and H.M. Abdullah (2017). Water Quality and Resident Perception of Declining Ecosystem Services at Shitalakkah Wetland in Narayangonj City. Sustainability of Water Quality and Ecology, DOI: 10.1016/j. swaqe.2017.03.002.

APHA, AWWA, and WEF (1998). Standard methods for the examination of water and wastewater. American Association of Public Health, American Water Works Association and the Water Pollution Control Federation, American Public Health Association, 20 ${ }^{\text {th }}$ Edition, Washington, D.C, 1268.

Basnet, B.K. (2010). Documentation of flora of Rara lake and adjoining areas in the mid-western region of Nepal. Banko Janakari, 21(1), 41-47.

Bhuju, D.R., S. Sharma, P.K. Jha, and N.P. Gaire (2012). Scientific discourse of lakes in Nepal. Nepal Journal of Science and Technology, 13, 147-158.

Buckland, S. T., D.L. Borchers, A. Johnsten, P.A. Henrys, and T.A. Marques (2007). Line transects methods for plant surveys. Biometrics, 63, 989998.

Field Methods for Vegetation Mapping (1994). USGS/NPS, Vegetation Mapping Program. United States Department of Interior, United States Geological Survey and National Park Service. The Nature Conservancy, $1815 \mathrm{~N}$. Lynn St. Virginia USA, Environmental Systems Research Institute, Inc. 380 New York Street.

Gurung, S., S. Sharma, and C.M. Sharma (2009). A Brief Review on Limnological Status of High Altutide lakes in Nepal. Journal of Wetlands Ecology, 3, 12-22.

Huang, X., B. Hu, P. Wang, X. Chen, and B. Xu (2016). Microbial diversity in lake-river ecotone of Poyang lake, China. Environ Earth Science, 75, 965.

Ivanova, Y. and V. Soukhovolsky (2016). Modeling the Boundaries of Plant Ecotones of Mountain Ecosystems. Forests 7, 271, DOI:10.3390/ f7110271.

Johnston, C.A., B.L. Bedford, M. Bourdaghs, T. Brown, C. Frieswyk, M. Tulbure, L. Vaccaro, and J.B. Zedler (2007). Plant species indicators of physical environment in Great lakes Coastal Wetlands. Great lakes Resources, 33, 106-124. 
Klosowski, S. (1993). The shore vegetation in selected lakeland in northeastern Poland. Hydrobiologia, 251, 227-237.

Kora, A.J., L. Rastogi, S.J. Kumar, and B.N. Jagatap (2017). Physico-chemical and bacteriological screening of Hussain Sagarlake: An urban wetland. Water Science, 31, 24-33.

Lemein, T., D.A. Albert, and E.D.G. Tuttle (2017). Coastal wetland vegetation community classificaltion and distribution across environmental gradients throughout the Laurentian Great lakes. Journal of Great Lakes Research, DOI: 10.1016/j.jglr.2017.04.008.

Lu, S., F. Chen, H.H. Ngo, W. Guo, C. Feng, J. $\mathrm{Wu}$, and B. Zheng (2016). Effect of straw and polyacrylamide on the stability of land/water ecotone soil and the field implementation. Ecological Engineering, 94, 12-21.

Nowak, A., E. Yazykova, M. Nobis, and A.A. Nikonov (2017). Can vegetation provide indications of ancient lake ecotones after more than one hundred years? A case study of Iskander-Kull lake, Tajikistan. Ecological Indicators, 81, 373-382.

Olubode. O.S., R.O. Awaodoyin, and A. Ogunyemi (2011). Floral Diversity in the Wetlands of Apete River, Eleyele lake and Oba Dam in Ibadan, Nigeria: Its Implication for Biodiversity Erosion. West African Journal of Applied Ecology, 18, 21-35.

Onorato, M.R., A. Coronato, L.P. Perucca, J. Rabassa, and R. Lopez (2017). MorphoBathymetry and surficial morphology of Udaeta lake, along with the Mangallanes-Fagnano fault system, Tiera Del Fuego, Argentina. Journal of South American Earth Sciences, DOI: 10.1016/j. jsames.2017.02.001.

Palmik, K., H. Maemets, M. Haldina, and K. Kangur (2013). A comparative study of macrophyte species richness in differently managed shore stretches of lake Peipsi. Limnologica, 43, 245253.

Patil, P.N., D.V. Sawant, and R.N. Deshmukh
(2012). Physico-chemical parameters for testing of water - A review. International Journal of Environmental Science, 3, 1194-1207.

Rai, A.K. (2000). Limnological characteristics of subtropical lakes Phewa, Begnas, and Rupa in Pokhara Valley, Nepal. Limnology, 1, 33-46.

Raut, R., M. Sharma, R.M. Bajracharya, C.M. Sharma, and S. Gurung (2012). Physicochemical Characterization of Gosainkunda lake. Nepal Journal of Science and Technology, 13, 107-114.

Reizopoulou, S., N. Simboura, B. Enrico, F. Aleffi, A. Basset, and A. Nicolaidou (2013). Biodiversity in transitional waters: steeper ecotone, lower diversity. Marine ecology, 35 (Suppl. 1), 78-84.

Singh, M. (2013). Ecological strategies for the sustainable management of Gujar Tal Ecotone Belts. Indian J. L. Sci. 2(2), 59-62.

Talukdar, D. (2013). Species richness and floral diversity around 'Teesta Barrage Project' in Jalpaiguri district of West Bengal, India with emphasis on invasive plants and indigenous uses. Biology and Medicine, 5, 1-14.

Teneva, I., G. Gecheva, S. Cheshmedjiev, P. Stoyanov, R. Mladenov, and B. Detelina (2014). Ecological status assessment of Skalenski lakes (Bulgaria). Biotechnology and Biotechnological Equipment. 28:1, 82-95.

Udhayakumar, R., P. Manivannan, K. Raghu, and S. Vaideki (2016). Assessment of physicochemical characteristics of water in Taminlandu. Ecotoxicology and Environmental Safety, DOI: 10.1016/j.ecoenv.2016.07.014i.

Verma, S. and J.B. Khan (2015). Analysis of Water Quality by Physico-Chemical Parameters in Fateh Sagar Talab in Bagar, Dist. of Jhunjhunu (Raj.), India. IOSR Journal of Pharmacy and Biological Sciences (IOSR-JPBS), 10, 41-45.

Received 18 July 2018 Revised accepted 20 Nov 2018 